\title{
The Novel after the Global Turn: Decentered Perspectives from the Spanish Literary Field $^{1}$
}

\section{Neus Rotger and Marta Puxan-Oliva}

\begin{abstract}
:
This essay addresses current debates on the global novel through the analysis of two contrasting yet comparable case studies: J. M. Coetzee's "Jesus" trilogy—The Childhood of Jesus (2013), The Schooldays of Jesus (2016), and The Death of Jesus (2019) — and the significantly less well-known novel Sudd (2007), by the Spanish novelist and travel writer Gabi Martínez. Mobilizing a growing body of criticism, we identify a key constellation of social, political, affective, and ethical concerns that are increasingly present in recent theories of the novelsuch as global interconnectedness and violence, cosmopolitanism, a new order of affects, humanitarianism, translatability, and planetarity_and discuss them through our two case studies. Working from different narrative aesthetics and unequal positions in the literary system, Coetzee and Martínez thwart exclusive adherence to normative or pragmatic approaches to the global novel, evincing the unevenness of international circulation and academic institutionalization against the backdrop of global Anglophone literature.
\end{abstract}


In May 2019, readers in Spanish were the first to enjoy the last and most anticipated novel in J. M. Coetzee's “Jesus” trilogy. Following The Childhood of Jesus (2013) and The Schooldays of Jesus (2016), The Death of Jesus appeared as La muerte de Jesús in Buenos Aires and Barcelona (El Hilo de Ariadna/Penguin Random House). It was translated by the Argentinian Elena Marengo and distributed to the Spanish and Latin American markets several months before its publication in English. Repeating a gesture Coetzee and his publishers had previously made with Siete cuentos morales ('Seven Moral Tales'), ${ }^{2}$ The Death of Jesus kept English readers waiting. It did not appear until October 2019, when the novel was published by the independent, Melbourne-based Text Publishing. Readers in the UK and the US had to wait almost a year: British press Harvill Secker released it in January 2020, and Viking only published it for the US market in May 2020 — after the publication of the Dutch version De dood van Jezus, translated by Peter Bergsma, by Amsterdam's independent Cossee Publishers.

Coetzee has explained this preference for Spanish (and Dutch) translations as a way of decentering the global publishing market and distancing himself from the Anglocentric vision of the world: 'I don't care if my books don't appear in English first. I don't like that English has taken over the world. I do what I can to resist that dominance,' he declared to the Spanish newspaper El País (Marín Yarza), after acknowledging that nevertheless, English is a language to which he owes his 'liberation from the narrow world of Afrikaner.' ${ }^{3}$ In his "Jesus" trilogy, Coetzee's attempt to move away from the Anglophone world also becomes a clear theme, for all three novels are set in an imaginary land where the native language is Spanish, and Cervantes's Don Quixote is a key influence on the protagonist's vision of the world. 
With the aim of delving into the meaning and scope of a global novel still under definition, we propose to analyze Coetzee's latest trilogy alongside the earlier and far less well-known novel Sudd (2007), by the Spanish novelist and travel writer Gabi Martínez. Combined, these novels display the poetics of the global novel but do not meet the established global-reaching, homogeneous standards with regards to their circulation. Intricate narrative issues involving translation, multilingualism, and multicultural scenes, as well as thematic concerns such as global civil war and neoliberal financial interests, are not only central to Martínez's novel but also attributed to the global novel specifically. Examined together, the "Jesus" trilogy and Sudd demonstrate the limitations of assuming that novels addressing global matters will circulate globally, for while there is critical agreement that Coetzee is one of the key authors of this emergent genre, Martínez has a very limited circulation in international markets, even Spanish-speaking ones, and remains completely outside of the scholarly debate.

In light of Coetzee's and Martínez's decentering examples, this article addresses a major question: whether the current models of the global novel, which often assume a homogeneous world market and a fluent correspondence between international circulation and poetics, successfully assess some of the genre's new avenues. Walkowitz, Ganguly (This Thing), and Kirsch describe the genre in terms of a global archive that newly engages with the world's conflicting forces, but how even is this archive? Can we really describe a worldconsciousness, or even a shared sense of an ethical and political global community, without considering the material conditions of international circulation? To what extent can authors as different as Orhan Pamuk, Haruki Murakami, Roberto Bolaño, Chimamanda Ngozi Adichie, Mohsin Hamid, J. M. Coetzee, Amitav Ghosh, or Elena Ferrante build worldly continuities? How does limited circulation impact the constitution of this corpus? And what do novels written outside this archive, like Martínez's Sudd, tell us about its pitfalls? A comparison 
between Coetzee's “Jesus” trilogy and Martínez Sudd shows that studies focusing only on poetics or circulation might reach contradictory conclusions with regards to the global novel. Ultimately, their comparison demonstrates the nodal tensions and challenges in this emerging field of study.

By producing a critical state of the art, this essay assesses the uses, scope and challenges of a growing body of criticism and literary theory that, from different theoretical perspectives and drawing on a varied set of contemporary novelists, is contributing to think the genre in global terms. We argue that while current still-evolving theorizations of the global novel offer meaningful insights into the nature, value, and behavior of a critical corpus of contemporary novels, there is still much work to be done in order to better understand this new trend in contemporary fiction. The primary goal of this essay is thus twofold: first, to systematize the existing literature on the global novel and identify the main nodes and challenges of this scholarly debate; and, second, to take these ideas further through an analysis of Martínez and Coetzee's case studies that considers how the two authors engage with global poetics and circulation in comparable yet very contrasting ways.

\section{A Critical Unfolding of the Global Novel}

In the context of global studies, scholars seem to agree that the novel no longer accounts for the nation, but rather for the world as an "imagined community"- to use Benedict Anderson one more time. They not only conceive of the genre in relation to the challenges of a post1989 world, such as hyperconnectivity, planetary environmental justice, and international human rights; they do so from a renewed self-awareness about the place of literary studies within the humanities and social sciences. Calls for collaborative and interdisciplinary work are becoming urgent in the study of global culture and society, ${ }^{4}$ and these collaborations are also opening up new ground in the study of the novel, where the effort to move beyond 
national frontiers has encouraged a redrawing of traditional disciplinary boundaries. From cross-disciplinary perspectives like ecocriticism, cosmopolitanism, and translation studies, novel studies scholars are connecting the genre to previously unacknowledged fields: literature and ecology, in the "planetary novel" (Keith) or "planetary petrofiction" (Tanaka); literature and human rights, in the "human rights novel" (Dawes "Novel"); literature and migration, in the "migrant" (Armstrong "Migrant") or the "expatriate novel" (Irr); or literature and translation, in "born-translated novels" (Walkowitz).

It is true that attention to the novel has been the hallmark of well-established theories of world and global literature. Closely linked to world and global literary studies but conducted through their own scholarly channels, discussions about the global novel as such, however, are fairly recent. Since O'Brien and Szeman's early special issue of 2001, reflections on the genre have spread rapidly, especially in the US but also beyond it. Key contributions by Annesley, Calabresi (Letteratura, Narrare), Gupta (Globalization), Bessière, Coletti, Walkowitz, Hoyos, Beecroft (Ecology, “Tropes”), Kirsch, and Ganguly (This Thing) account for the emergence of a new field. In 2016, leading institutions and journals such as the newly founded Society for Novel Studies (SNS), in association with Novel: A Forum on Fiction, celebrated its first biennial conference confronting the novel "in or against world literature" (Marx and Armstrong), and at least two panels at the ACLA's 2019 Annual Meeting were entirely dedicated to the global novel. ${ }^{5}$ The same year, the Institute of the Humanities and Global Cultures at the University of Virginia and the journal New Literary History co-sponsored a symposium on the subject, which has just been published into the special issue "The Global Novel: Comparative Perspectives" and which also positions itself against straightforward assumptions of global exchangeability (Ganguly “The Global” vi). ${ }^{6}$ This upsurge of focus on the global novel within literary studies has fueled new debates around the theory of the novel, like those related to the genre's autonomy or the 
return of genre theory as a useful tool for conceptualizing the novel in the era of globalization. ${ }^{7}$ No general consensus has emerged, however, about the definition of the genre, which still spurs heated discussion. This is clear, for instance, in the varied and sometimes competing terminology employed. The specificity and value of the term "global" novel (Morace, Kirsch, Haley, Jackson, Rosen, Hoyos, Erwin) often competes with a variety of other tags, such as "world” (Ganguly This Thing, Irr, Coletti, Morace, Denning), “international” (Nadiminti), "transnational” (Jay), "cosmopolitan" (Shaw Cosmopolitanism, Levin), or "planetary" novel (Keith, Heise, Taylor), and it collides just as much with other overlapping labels and expressions such as "fictions of the global" (Barnard "Fictions," O'Brien and Szeman), "fictions of globalization" (Annesley), or "the globalization of the novel and the novelization of the global" (Siskind).

The most elaborated distinction between "world," "global," and "planetary" points at three different approaches to the novel. Stemming from an effort to amplify the postcolonial de-Orientalizing move, the term "world" mostly affiliates the novel to a critical perspective (Casanova, Moretti, Damrosch, Beecroft) that detaches itself from the term "global," which is sometimes accused of referring to the capitalist and neoliberal political effects operating in a global market (Apter, Walkowitz, Habjan). In light of criticisms of the term "world" as apolitical and thus complicit with neoliberal globalization's tendency to privilege certain elite academic sites of enunciation (Apter, Hoyos, Siskind), the term "planetary" has arisen with a more political agenda that deliberately seeks to encompass a multicultural, diverse planet (Spivak, Keith, Taylor, Moraru Reading). This term has later been aligned with post-human concerns, specifically those theorized from the ecology-centered perspective of ecocriticism (Heise) ${ }^{8}$

The attempts to define and even posit as opposites ${ }^{9}$ these three competing approaches — the world, global and planetary novel—reveal a deep discrepancy between an 
aesthetic, normative understanding of the genre, on the one hand, and a more materialistic approach that is attentive to the economic and political pressures of the global market, on the other. As we will argue, the distance between these two approaches cannot be dismissed, since the discrepancy between them lies at the center of most unresolved issues surrounding the global novel. Aesthetic and thematic definitions of the global novel criticize the overdeterministic nature of more material approaches that pay attention to massive circulation through the capitalist publishing industry, choosing instead to celebrate the novel's worldliness; that is, the novel as "an active power of world making that contests the world made by capitalist globalization" (Cheah 303). Materialist, pragmatic definitions of the genre, in turn, call out the idealism — and elitism—of aesthetic, normative views, which are of clear Heideggerian descent, and question both the alleged autonomy of the novel and its performative agency in the world. Spatial circulation, material and historical conditions of production, translation, reception, and institutionalization are key to these pragmatic approaches, under which the study of materiality in literary fields does not necessarily imply a derivative conception of the novel, or the novel's complete assimilation to the global capitalist market. ${ }^{10}$

By acknowledging the tension between poetics and material conditions while trying to avoid its limitations, we aim to identify some key critical concerns that span both sides of the global novel debate, in order to test them through the analysis of our case studies. Both Coetzee and Martínez demonstrate (and resist) the value (and pitfalls) of current theorizations of the genre. Coetzee's “Jesus" trilogy and Martínez's Sudd display the specific concerns and features that critics addressing the global novel have identified as common. Nevertheless, when viewed from the perspective of their material conditions of circulation, the novels operate in radically opposed ways. Among others, we identify a set of notions that critics focusing on the poetics of the global novel recurrently work with: interconnectedness, global 
violence, cosmopolitanism, affect, humanitarianism, translatability, and planetarity. These concepts are increasingly present in recent theories of the novel, and they signal a productive path towards a working definition of the genre. These key social, political, affective, and ethical forces do not appear simultaneously or homogeneously in the emergent corpus of global novels, but they generate fertile perspectives that cross various vectors, mostly narratological and thematic.

Global interconnectedness is one of the main concerns across both sides of the global novel debate. Annesley proposes that narratives such as Don DeLillo's Underworld (1997) explore interconnectedness by experimenting with techniques such as a narrative structure based on lines of connection in order to describe "the network of connections that characterize globalization" (65), and contradiction in order to challenge "the readings of globalization in terms of homogenization and coordination" (73). This hyperconnectivity promotes new ways of understanding a shrinking global time and space that, as De Blasio suggests, "si riflette nel romanzo contemporaneo dissolvendo ogni ancoraggio spaziale: i luoghi diventano scenografie interscambiabili" ("is reflected in the contemporary novel's dissolving of each spatial anchoring: places become interchangeable scenographies,' 17). From a technical standpoint, this shrinking and hyperconnectivity drive novelists to represent "temporal simultaneity" and multiple geographies (Barnard "Fictions" 207) and temporal networked structures (Edwards 16), as well as to employ more fitting narrative plot strategies, such as Hoyos" "emplotment of globalization" (2) and the multi-strand plot that Beecroft (“Tropes") distinguishes as "the plot of globalization," experimented in novels such as David Mitchell's Ghostwritten (1999) and films like Alejandro González Iñárritu's Amores Perros (2001) and Babel (2006). ${ }^{11}$

Global violence is another distinguishable concern in the debates around the new genre. Narratives of globalization use multiple, intertwined characters and stories to reveal 
the interconnected nature of problems that go beyond national borders $\left(\mathrm{O}^{\prime}\right.$ Brien and Szeman)—problems intrinsic to globalization, such as "world crime syndicates, labor migration, tourism and terrorism" (Barnard "Fictions" 211). Some novels, for example, contribute to shaping and exposing a crisis discourse-for Dan and Wajno-Owczarska, this trend is inherent to globalization —or to shaping particular aesthetics, like that of the 2007-8 financial crisis (Gupta "Crisis") or that of nuclear disasters (Jiménez). Global violence novels deal with drug traffic wars, as in Roberto Bolaño's Los detectives salvajes (1998) and 2666 (2004); ongoing international wars, like the Iraq War in Ian McEwan's Saturday (2005); contemporary narratives about colonial wars, such as the Opium Wars in Amitav Ghosh's Ibis trilogy (2008-2015); or global terrorism, as in John Updike's The Terrorist (2006) and Richard Flanagan's The Unknown Terrorist (2006).

Global violence has renewed interest in a literary and critical ethical perspective and commitment, which has led critics to engage with new cosmopolitan perspectives in literature. Referring mostly to Nussbaum, Appiah, Mignolo, Delanty, and Cheah, global and world novel critics like Shaw (Cosmopolitanism), Barnard ("Fictions"), and Ganguly (This Thing) draw on the backbone idea of ethical cosmopolitanism: that literature helps us reflect on the possibility of achieving global citizenship and an ethically responsible community by means of addressing intercultural relations and stories in narrative. In highlighting the cleavages produced by globalization and showing the geographic inequality and economic disparity it generates (Shaw "Globalization” 34), a significant group of novels produce a global consciousness that would hold "the potential to be a facilitator of cultural convergence, acting as a potent mechanism in the spread of ethical values, and opening established national allegiances or ethic ties up to a more cosmopolitan ethos .... In this regard, cosmopolitanism emerges as a response to globalisation" (Shaw Cosmopolitanism 9). This is seen in novels that address multicultural encounters and display the contemporary 
world's massive migration, travel, exile, and expatriation. Examples include Teju Cole's Open City (2011), Zadie Smith's NW (2012), Chimamanda Ngozi Adichie’s Americanah (2013), and Junot Díaz’s The Brief Wondrous Life of Oscar Wao (2007).

These new cosmopolitan communities have also produced a concern for new affects that novels cannot respond to in the same manner as the traditional family-based domestic novel (Armstrong "Future," “Affective," Berman) does. Armstrong's idea of what comes after family — "a community of human beings violently detached from the traditional sources of feeling" ("Future" 9) — has prompted a renewed humanitarian ethics of the novel form. Barnard has referred to this ethics as "a kind of globalization of compassion" ("Fictions" 209); Kirsch describes the novel's attempt "to reckon with humanity as such" (13); and Ganguly argues for a new "humanitarianism" (This Thing 1-37) that furthers the important work on the novel and the human rights discourse done by scholars like Slaughter or Anker. More recently, Dawes ("Novel") has distinguished "the novel of human rights" as a subgenre of the contemporary novel that uses distinctive narrative devices such as the "justice plot" and the "escape plot," although his analysis is limited to US fiction.

Another concern that we consider key in the global novel debate is multilingualism and translation. Walkowitz branded the "born-translated novels" as works that are written for translation and as translations; that is, works "pretending to take place in a language other than the one in which they have, in fact, been composed" (4). This approach considers translation as a means of achieving global circulation and gaining "worldwide audiences" for leading figures in the pantheon of world literature (Kirsch 22). However, uses of multilingualism and translation might prove more contextually and intertextually elaborate than Walkowitz considers, even hindering circulation, since translation can be used to add layers of cultural references, as Morace and Bencomo argue, making reception more complex. Sociological scholarship, with its critical interest in assessing the scope (Levin, 
Nadiminti) and limitations (Sánchez-Prado, Aguilar, Horta) of circulation and global and national markets, uncovers assumptions that reveal the global novel corpus to be a contradictory one, as we will see later in this essay.

Finally, we can identify a growing concern for the planet, not only in its multicultural planetarity (Spivak, Keith), but also in its environmental sustainability, which is at risk in the age of the Anthropocene (Heise "Globality"; Boes; Taylor). This age has produced novels troubled by massive oil drilling, as in Frank Schätzing's Der Schwarm (2004), or by rising sea levels, as in Paolo Bacigalupi's The Windup Girl (2009). In many instances, these novels use science-fiction techniques (Heise Sense), epic narrative modes (Boes), and global environmental settings.

\section{Contrasting Poetics and Circulations: The Global Novel at Work}

At once an object and an agent of globalization, the global novel is generally discussed as a narrative form concerned with pressing global issues like the ones analyzed above. Yet paying exclusive attention to the novel's poetics, on the one hand, or the various ways in which it circulates within the global market, on the other, tends to lead to partial, if not misleading conceptions. In this section, we will analyze the similar poetics and contrasting circulation of Martínez's Sudd and Coetzee's “Jesus” trilogy so as to shed light on some of these conceptions, as both case studies thwart exclusive adherence to poetic and materialist approaches to the global novel in its critical examination. These similarities and contrasts show the challenges in producing a clear conceptualization of the "global novel".

\section{Gabi Martínez, Sudd (2007)}

The non-Spanish Peninsular reader will most likely be unfamiliar with Gabi Martínez, a Spanish writer, journalist, screenwriter, and traveler born in Barcelona in 1971, better known 
for his non-fiction than his novels. Reviewed by well-known literary critics in the Spanish press, Martínez has been placed among a young generation of Spanish avant-garde authors who are breaking away from the novel's nationally-centered tradition. He has been included in the so-called "generación Nocilla" (Gil González) due to the way he thematizes globalized society by means of genre hybridization, imbrication with media (as in Ático, 2004), play with the borders of fiction and documented fact, and exploratory settings in diverse territories around the world (Africa in Sudd, 2007; China in Los mares de Wang -'Wang's Seas,' 2008; Pakistan in Solo para gigantes -In the Land of Giants, 2011; and New Zealand in Voy'Coming,' 2014, among others).

Sudd tells the story of a group of people from different nationalities in a peace mission seeking to end a 20-year civil war and rebuild "the City" in an unnamed country in inland Africa near the biggest swamps on Earth, Sudd, which they have to cross in a ship. The ship gets trapped between floating vegetal islands, which creates an emergency situation that results in a resource shortage and a conflict over authority. By using his multi-lingual skills, the narrator becomes the ship leader, the "omnipotente gobernador del caos. Gobernador del Sudd” ('omnipotent governor of chaos. Governor of Sudd,' Martínez 265). ${ }^{12}$ Thematically and formally, it is hard to find a novel that more clearly suits discussions about the poetics of the global novel. Sudd unites the core concerns stated above: cosmopolitanism, global capitalism, planetarity, and multilingualism and translation. It problematizes cosmopolitanism by putting into play a set of characters whose definition relies on individual experiences linked to cultures, languages, and conflicts in their original countries. The novel gathers a group of local tribal leaders; a cruel Sudanese war soldier and his sick wife; a Canadian photographer; a French biologist; an English oil company businessman; five Chinese real-estate businessmen; a local minister; the captain and his 
daughter; Spanish and Chinese translators; and a large, nameless group of local tribal warriors and people.

Only the choice of a cosmopolitan situation in Sudd enables the novel's conflict to happen, since the plot develops from a linguistic and cultural misunderstanding: the narrator leads the people in the "inferior level" of La Nave (the Ship) to believe that a revolt against the food rationing policy has already started, instigating a mutiny. This situation might be explained through Deer's concept of “cosmopolitan scene," a device which has not yet been introduced into global novel studies. A cosmopolitan scene refers to a kind of scene where characters from different cultures gather and perform a misunderstanding or confrontation, which Deer calls "making a scene" (253). Cosmopolitan scenes are common in novels concerned with the global, such as Roberto Bolaño's Los detectives salvajes (1998), David Mitchell's Ghostwritten (1999), Zadie Smith's White Teeth (2000), Amitav Ghosh's Ibis trilogy (2008-2012), or Mohsin Hamid's Exit West (2017). This cosmopolitan scene in Sudd not only represents the international dimension of a localized conflict by involving all the multinational interests in the Sudan region in the peace treaty; it narratively enables the conflict to happen.

The kind of cosmopolitanism that forms the backbone of Sudd's plot is not, however, in line with Shaw's cosmopolitanism, which assumes the idea of global citizenship and calls for a global ethics that could be mistaken for the narrator's satisfaction to "sentirme cosmopolita" ('to feel cosmopolitan,' 31). Rather, it is closer to the conflictive and neoliberal uses of cosmopolitan discourse and operations highlighted by Robbins's argument in The Beneficiary, where cosmopolitanism is an ideological discourse about the global leveraged to favor capitalist interests elsewhere. Indeed, La Nave's expedition is financed by the English oil company Norton, and it seeks “gente simbólica” ('symbolic people,' 17) to configure a cosmopolitan team that would perform "un hecho significativo" ('a significant event,' 17) so 
as to show the world a peace mission that will end the globally infamous horrors of the civil war. This mission is tailored to produce a visually powerful global message of international agreement — one of those codified war images that operate through what Ganguly explains as the "mediatization of distant suffering, and the emergence of a humanitarian sensibility" (This Thing 37) in a kind of story that she understands as characteristic of the novel as a global form. In Sudd, international and local powers artificially construct the cosmopolitan scene in the service of a spectacular, global ethical and humanitarian response that will in fact acquiesce to the capitalist interests in the area. Ironically, though, the media operation is truncated when La Nave gets trapped in the Sudd swamps and the ship's communication system is cut off. The cosmopolitan scene in this case sinks into an invisible yet major violent conflict where the most powerful individuals take advantage of the lack of witnesses, revealing the dark side of cosmopolitan encounters.

The use of an open, natural space as the novel's setting makes this narrative situation possible. The Sudd swamps are read as "un laberinto móbil” ('a moving labyrinth,' 56), “un reino sin límites, de confines corredizos" ('a limitless kingdom of moving borders,' 56), one of those type places that, according to Rosen, global novels find most productive for representing a neutralized yet interconnected world. In this case the setting is not an airport, hospital or supermarket, but a vast natural space, similar to other global environments such as deserts, oceans, or jungles. Furthermore, as the narrator and the biologist's reflections suggest, the swamp brings the events to a planetary level, as "Norton y su gente ... no respetan los mínimos naturales. Solo quieren ganancias, petróleo, y venga a perforar, perforar, perforar, y a gasear, gasear, gasear. Eso sí es un problema serio, ¿ve? Van a cargarse el planeta, van a destrozarlo todo" ("Norton and their people ... do not respect natural basics. They only want benefits, oil, and drilling, drilling, drilling, and gas, gas, gas. That is a real problem, you see? They are going to destroy the planet, devastate it,' 61). The Sudd swamps 
also offer the opportunity to establish and negotiate social rules anew. However, the outcome is rather pessimistic: since the characters are lost and trapped in this muddy, vegetal environment, the effort to build of a multicultural cohabitation ends in death, starvation, power struggles, and gross inequalities.

Sudd's most remarkable aspect is probably the way Martínez creates the novel's central conflict through translation. In alignment with the contemporary global novel's aforementioned interest in multilingualism and the role of translation, Martínez's novel features a Spanish translator who is an unreliable narrator. In this way, it resembles the alsountranslated Catalan novel Gegants de Gel ('Ice Giants,' 2015), by Joan Benesiu, which deploys unreliable narration in cosmopolitan scenes. The reader's suspicions arise from the narrator's own comments and resonate in a "traduttore traditore" manner when he provides Spanish translations of multilingual conversations on board-reproducing the dialogue in Spanish even as he often indicates the other languages in which the exchanges occur. On several occasions, the narrator provides sentences in transliterated Chinese; some are accurately translated while others are left untranslated. In the aforementioned central episode, the narrator orders a Chinese outcast to say to the people on board some ill-intentioned words and mistranslates others in order to make the passengers on the ship's lower level believe a mutiny is happening and change alliances. Undiscovered, the translator earns money, food, and sexual favors, regaining power while working for both sides simultaneously. He is protected by the fact that he is the only one who understands all the languages on board. At this point, the reader recalls the translator's earlier efforts to maintain conviviality on board, like when he softened the insulting words of a French, female passenger (30), prompting her to remark "cualquiera se fía de ti" ('who would trust you?' 42). The licenses he took earlier now appear to have been weapons of manipulation all along, and the reader is left distrusting the translator's complicit narration and questioning his translations from Chinese and all the 
translated dialogue in the novel. In Sudd, multilingualism and translation are tools for gaining political and narrative power.

For all these reasons, Sudd is, as an early review of the novel suggested, "un perfecto símbolo de la globalización” ('a perfect symbol of globalization,' Hevia). Like Coetzee’s trilogy, it would perfectly suit the features discussed in scholarly debates on the global novel. Nevertheless, in contrast to Coetzee's, according to definitions of the global novel that assume circulation in global markets, it would be hard to think of Martínez's Sudd as one. Sudd has only been translated into Serbian and adapted into a graphic novel by Tyto Alba (Mladinska knjiga, 2009) with scarce circulation. The presumed correlation between "borntranslated" global novels and a wide international circulation is not present here, as it is in Coetzee's, despite his resistant gestures. While the reception of Sudd was very limited, Martínez's other works have been praised by prestigious journalists like Jacinto Antón and John Carlin, and his only book available in English, Solo para gigantes (In the Land of Giants, Scribe, 2018), was translated by the renowned Daniel Hahn, reviewed by Kirkus and The Spectator's Sandra Wheeler, and adapted into a graphic novel again by Tyto Alba (Astiberri, 2012). Yet while Martínez's circulation has increased, it would certainly be an exaggeration to call him a global author. For $S u d d$, not even international readability and the natural connection with readers abroad offered by cosmopolitan scenes, planetary settings, multilingual conversations, global violence, and shared capitalist concerns have guaranteed any reach beyond the Spanish-speaking literary markets. In Martínez's case, the success of his novels' global poetics and their international circulation are almost opposite.

\section{J. M. Coetzee's “Jesus” trilogy (2013-2019)}

It is worth comparing Martínez's Sudd to Coetzee's “Jesus" trilogy to observe their sharing of similar poetic features and concerns, as well as their different circulation conditions and 
results. Taken alongside widely cited authors including Don DeLillo, Margaret Atwood, Amitav Ghosh, David Mitchell, Zadie Smith, Teju Cole, and Chimamanda Ngozi Adichie, the South African-born Nobel Laureate J. M. Coetzee is often considered a preeminent reference point for the contemporary global novel. ${ }^{13}$ In Coletti's view, for instance, "i grandi romanzi di questo magnifico autore sono davvero del mondo, anche quando è ben visibile l'ambientazione locale" ('the great novels of this magnificent author are truly of the world, even when the local setting is clearly visible,' 67-68). Coletti also attributes this global dimension to Coetzee's literary criticism, arguing that he displays, like other "grandi romanzieri internazionali" ('great international novelists') and "naturali abitatori del mondo letterario" ('natural inhabitants of the literary world,' 116), a special ability to measure himself "col romanzo del villaggio globale" ('against the novel of the global village,' 117). Haley describes Coetzee's Disgrace (1999) as “one of the most widely read works of what Beecroft calls global literature" (105); while for Walkowitz, the author's recent work signals a decided turn "to the making of world literature, and to the relationship between production and circulation"- and his Elizabeth Costello (2003) is "a classic example of world literature" (57).

Because he is celebrated as a global novelist, Coetzee's gesture towards decentering the circulation of his books by clearly privileging Spanish and Latin American markets invites reflection on the hegemonic role of the British and US circuits in shaping global literature and culture, and the critical assumptions derived from it. Avoiding what Coetzee ("In Conversation") calls "the cultural gatekeepers of the metropoles of the North," "who decide which stories by the South about itself will be accepted into the repertoire of world literature and which will not," the decision to publish first in Spanish and other non-English languages like Dutch is a clear political gesture against the economical and ideological hegemony of global English. ${ }^{14}$ Interestingly enough, while the Spanish-language press has 
highlighted the relevance of Coetzee's gesture, United Kingdom and United States media outlets have tended to ignore it, even though The Death of Jesus was widely advertised as one of the most anticipated novels of 2020 in the English-speaking world. ${ }^{15}$

In Coetzee's most recent fiction, his characters also show a curious predilection for Spain, as in "A House in Spain" (2000), included in Three Stories, and "La anciana y los gatos" ('The Old Woman and the Cats,' 2013), compiled in Siete cuentos morales. ${ }^{16}$ Like the protagonists of those short stories - a man in his fifties and the very same Elizabeth Costello - the protagonists of Coetzee's "Jesus" trilogy move across the ocean to a fictional Spanish-speaking town, where a new life awaits. And, as in those stories, all three novels in the series-The Childhood of Jesus (2013), The Schooldays of Jesus (2016), and The Death of Jesus (2019) — highlight the question of language. The trilogy's characters, newly arrived in a foreign country after a sea crossing during which they have forgotten their real names, their identities, their past, and their language, spend the first days of their new lives in a relocation center, where they are taught Spanish, the country's language, and assigned new names.

Simón and David, a middle-aged man and a five-year-old boy who has been separated from his mother, start their adventure at this fragile point, hardly knowing anything about each other or themselves. In the trilogy's third book, as in The Schooldays of Jesus, David, Simón, and Inés (the boy's adoptive mother) have settled down as a family in the new town of Estrella, where David has now fallen prey to a mysterious disease. Five years have passed since they first arrived in the small town of Novilla, but the language that Simón had found so hard to master then-those "Spanish words that do not come from our heart" (Childhood 77) — no longer seem to be an impediment to self-knowledge, or at least that is what he tells David during one of their conversations: "Who was I, Simón, before I crossed the ocean? Who was I before I began to speak Spanish?” (Death 13). 
In what can be interpreted as an attempt to provincialize the novel, instead of globalizing it, ${ }^{17}$ Coetzee's strategy of positioning himself and his fiction in an alternative relationship with the prevalence of English also functions as a thematic, conceptual, and formal device. Throughout the pages of all three novels, Coetzee often cites Spanish words and expressions and reproduces parts of the dialogue in this language, thematically and formally reflecting on the foreignness of both the story (the characters and the community they settle in) and Coetzee's own writing, thus problematizing the affiliation of the original text with a unique national and linguistic tradition. The trilogy is therefore "born translated," after Walkowitz's hypothesis, in at least two ways: pragmatically, for the novels premiered in Dutch (The Childhood of Jesus, The Schooldays of Jesus) and Spanish (The Death of Jesus) rather than English, and thematically or structurally, for all three novels are written as translations; that is, they pretend to take place in Spanish as a way to "remind us that English has not always been the principal medium of literary circulation." 18

Materialistic and poetic views merge here to "think together the material world in which the novel moves and the literary world that the novel opens up" (103), as Haley suggests in his work on Coetzee. Delving into the "global ethos" of the novel (105) and, more particularly, into Coetzee's capacity to circulate stories of marginal experience globally, Haley analyzes the worldly and cosmopolitan implications of his fiction through the lens of Nussbaum, Black, and Palumbo-Liu's accounts of border-crossing novels and their potential to give ethical form to our globalized present. In the case of Coetzee's latest trilogy, this cosmopolitan ethics becomes salient in the interplay between David, Simón and Inés, three marginal figures whose struggle for love and survival takes place in a transition camp, at first, and later amidst the sinister authorities of the imagined towns of Novilla and Estrella. The uprooted nature of the protagonists - a precocious orphan boy and his adoptive parents, refugees washed of their past and memories - influences their relationship with the sinister 
state authorities. They flee from these authorities in The Childhood of Jesus, and they hide David from the census in the second novel: "You don't have a name, you don't have a number. That is enough to make you invisible," Simón explains to the boy. "But don't worry, we can see you. Any ordinary person with eyes in his head can see you" (Schooldays 255).

As is the case for many migrants and expatriates across the globe, in Coetzee's slow allegory, the experiences of alienation, estrangement, and marginality reveal the covert violence of the state towards non-citizens without rights. ${ }^{19}$ Simón and Inés have no rights to David, their beloved son who is not really their son, and they are forced to abandon him to the orphanage of Dr. Julio Fabricante, where he will be able to be "a real orphan" (Death 4). And they have no rights later on, when the boy is sent to the hospital, nor when it is time to decide what to do with his remains. At David's tomb in the orphanage, the inscription reads: "David, Recordado con afecto" (Death 173); the word "afecto," "affection," here devoid of all meaning. Simón's family — which was never a proper family, as the insidious Dmitri cares to remind him ("the truth is, you were never a happy family, never a family at all" 179)— points to a whole new order of affects in the sense theorized by Armstrong, that is, "a community of human beings violently detached from the traditional sources of feeling" ("Future" 9). As Coetzee shows in this tale of stepfather and stepson (David/Jesus), which is not in itself a new thread in his fiction, ${ }^{20}$ the traditional family (and the type of domestic realism that it gave rise to) has shifted towards a strange new form of affective community that, in turn, is shaping a growing body of contemporary fiction.

As for Coetzee's well-known concern for the planet and its inhabitants, human and non-human, it is worth mentioning how the trilogy immerses the reader in a dystopian world where the relationships are marked by love and affection as well as by violence and conflict. This is clear in the central storyline of The Schooldays, with Dmitri's puzzling crime, but also in smaller episodes, most of them involving animals, like the old mare named El Rey who is 
sacrificed by its owners (Childhood 233-37), the cruelty of the farm children towards the ducks (Schooldays 6-12), or the altercation between the old dog Bolívar and the lamb (Death 96-7). Also, the fact that all three novels happen in a world that does not exist yet but also seems past, with hardly any marks of a specific time or place, situates the story and its characters in a sort of deterritorialized afterlife where we all come to die and be born again somewhere else, with another name, perhaps speaking another language.

Although Martínez and Coetzee work from different narrative traditions and unequal positions in the literary system, both authors explore global concerns and aesthetic features around which current discussions on the global novel are rapidly developing. As demonstrated in the analyses of both case studies, the problem of language and translation prompts cosmopolitan conflict within very diverse communities: a multilingual expedition in the heart of Africa, in Sudd, and a group of refugees arriving in the fictional Spanishspeaking country of Coetzee's trilogy — each one generating its own set of affective relations. Martínez uses cosmopolitanism formally, to create confrontational scenes that reveal the links between cosmopolitan discourses and global capitalism and violence, while in Coetzee cosmopolitanism serves to highlight an ethical perspective with regards to global marginal figures suffering from state violence. ${ }^{21}$ Finally, where Martínez emphasizes the planetary dimension by setting Sudd in vast swamps where new social rules may be established, Coetzee deploys the planetary to create a dystopian sense of the planet and our role within it. As our analysis of the novels makes clear, these two novels target a similar set of concerns, which are developed by other novels in the emergent corpuses of the global novel mentioned above. This enables us to see them on a common ground, perfectly fitting an approach that exclusively focuses on form and theme, on literary representation and narration, leaving nuanced considerations about circulation and market aside. 
Although our test cases might follow the current poetics of the global novel as developed in the reviewed scholarship, the fact that their material circulations and literary statuses are profoundly asymmetrical poses questions that call for a response. It is here where our comparison and contrast of the selected novels is revealing. While it might be assumed that a global novel poetics might trigger global circulation, it is not at all clear that this is so. Recent sociological approaches illuminate some of these questions and help dismantle certain theoretical assumptions, especially the premise that circulation occurs globally and homogeneously. Comparing Coetzee and Martínez sharpens our understanding of the variables and specificities of the circulation of novels that might be understood as global from a poetical point of view. When observed closely, circulation of these products is profoundly uneven, as in the case of the "Jesus" trilogy and Sudd. This comparison participates of this recent sociologist approach that understands that the "world-literary system" has a "combined and uneven development", as the Warwick Research Collective argues (1-48) and that the neoliberal cultural practices that help build a robust unequal literary market are also diverse and heavily depending on their specific contexts (Deckard and Shapiro 3-5).

For example, international conglomerates like Penguin Random House/Alfaguara in Latin America and Spain operate in a decentralized manner, through a mixture of national and international market-driven strategies that result in profitable-but-uneven paths of distribution and circulation (Locane 66-7). As a result of the centripetal dynamics of the global publishing market, perhaps, global novel scholars tend to focus on a corpus that has been produced, circulated, and deemed prestigious in the Anglophone literary field. Even in those cases in which authors' non-US origins or filiations are emphasized, as with Chimamanda Ngozi Adichie, Bilal Tanweer, Kiran Desai, or Mohsin Hamid, it is telling that the first three have all undertaken Creative Writing master's programs in the U.S. (Nadinminti), and Hamid received both a bachelor's and a J.D. from Ivy League institutions. 
A similar argument can be made about the weight of the global economy of cultural prestige (English), with the growing influence of international book prizes, such as the Booker Prize, which might have created its own cosmopolitan aesthetics (Levin), or the Nobel Prize's canonization effects.

In the same vein, if we look at the difficulties encountered by now-enthroned Latin American global authors of the 20th century like Carlos Fuentes or Roberto Bolaño, in their efforts to publish in New York, it becomes apparent how "in postwar American foreign lists, the pressure to domesticate was not to an international literary field, but to the very specific fissures and pressures of an American market" (Horta 1). The example of the Mexican author Jorge Volpi-who favored German and Central European references and dialogue and refused to feed the global market's demand for exoticism from Latin America—offers yet another argument for problematizing the global dynamics of the publishing sphere, for it questions "the idea that cosmopolitanism and nationalism are mutually exclusive, or that Latin American writers must relinquish entire parts of their intellectual genealogy in order to appease market or academic demands" (Sánchez Prado 99). Also paradigmatic in this sense is the case of Clarice Lispector, who is acclaimed in world literature anthologies as the stand-in for Brazilian literary specificity, even as her previous difficulties with the national and international circulation of her work are ignored (Aguilar). Value standards, institutional prestige, and material conditions of production generate different circulation patterns and establish new literary canons that often leave little room for young, foreign authors (and especially female authors) writing outside the commercial and institutional Anglophone networks.

The choice to privilege a small, independent Argentinian publishing house like El Hilo de Ariadna (and the not-so-peripheral Penguin Random House in Buenos Aires and Barcelona) is yet another example of Coetzee's continuous attempt to disrupt the terms under 
which cultural capital accrues (Van Der Vlies). These decentralizing gestures matter to authors like Martínez, who has written a remarkably engaging global novel outside the institutional channels of prestige to little international attention. Martínez's Spanish offers no resistance to translation; commenting on In the Land of Giants, translator Daniel Hahn explains that "[i]t wasn't a difficult piece of work in terms of the writing — Gabi's style is crystal-clear for the most part, not too fussy." 22 And yet, the market constraints and preferences are in place, hindering the circulation of his works, albeit their deliberate global appeal.

These aspects considered, what do we learn, then, about the global novel scholarship chosen corpuses and limited approaches? Do a resistant author like J.M. Coetzee and a barely visible one like Gabi Martínez comfortably suit the purpose? If they do, only very polemically or partially so. Global aesthetic challenges and material circulation paths are, in and of themselves, valuable phenomena to investigate and compare. However, what the contrasting cases of Coetzee and Martínez demonstrate is that we need to push the study of the emerging "global" novel towards an articulation of aesthetic and material perspectives that provide less strained, uneven corpuses and a more nuanced approach to a very heterogeneous, yet still intelligible phenomenon. Ours is, therefore, an invitation to weigh the potential ethics and transformational power of novels along with the actual material conditions of their production, circulation, and critical reception. Meanwhile, we will await the critical assessment of how Coetzee's latest trilogy works in the interstices between two languages, and for an editorial project to embark on the translation of Martínez's novels.

\section{Neus Rotger (Universitat Oberta de Catalunya) and Marta Puxan-Oliva (Universitat Oberta de Catalunya and Universitat de les Illes Balears)}


1. We are grateful to Paulo Lemos Horta and to Jorge Locane for all their useful suggestions. 2. Siete cuentos morales was also translated by Marengo and was published in 2018 by the same publishing houses; the compilation is not yet available in English.

3. "No me importa que mis libros no aparezcan primero en inglés. No me gusta que el inglés se haya apoderado del mundo. Hago lo que puedo para resistirme a ese predominio', dijo tras reconocer que, con todo, es una lengua a la que debe su 'liberación del estrecho mundo del afrikáner."' Translation from the Spanish interview is ours. On Coetzee's attitudes towards Afrikaans, Dutch, and English, see Barnard (“Coetzee”). See also Viljoen's nuanced interrogation of the conditions of circulation of Afrikaans literature in relation to World Literature, through the contrasting cases of Koos Prinsloo and S.J. Naudé, which also show the different outcomes of their circulation contexts and the authors' gestures.

4. See Rotger, Roig-Sanz, and Puxan-Oliva.

5. "Properties of the 'Global' Novel," co-organized by Sangeeta Ray and Jeanne Marie Jackson; and "The Global Novel."

6. Convened by Debjani Ganguly, the symposium "The Global Novel: Contemporary Perspectives” gathered specialists like Ignacio Sánchez Prado, Rebecca Walkowitz, Ranjana Khanna, Daniel Y. Kim, and Baidik Bhattacharya.

7. See Alonso; Armstrong and Montag; and Habjan and Imlinger, respectively.

8. See Moraru "'World".”

9. See Cheah "World," and Kern.

10. See Brouillette, Helgesson/Vermeulen, Marling, Sánchez Prado, Locane, Horta, and Domínguez.

11. While we have identified a few experimental narrative techniques that contribute to represent globalization, we concur with the idea argued by Huehls and Smith that, under the present phase of 
neoliberalism, literary works have turned to realism and that globalization and neoliberalism are mostly thematized. This idea is displayed in the chapters dealing with literary form. Their edited volume is also interesting because it works with the conviction that the material conditions of circulation and institutionalization should be considered along with literary poetics.

12. All translations are ours.

13. See, for instance, the novelistic corpus convened in the works of Barnard, Armstrong, Irr, Erwin, Walkowitz, Haley, Beecroft (“Tropes”), Kirsch, Ganguly (This Thing), or Shaw. 14. See Attridge. In addition to prioritizing the Spanish-language publication of his later works, through translations by Spanish and Argentinian translators (Miguel Temprano García, Javier Calvo, and Elena Marengo), in recent years Coetzee has significantly strengthened his ties with the South: there is a literary prize with his name in Chile, and a chair of the University of San Martín, in Buenos Aires, which promotes relations between writers in Argentina, South Africa, and Australia. In Buenos Aires he also conducts periodic readings at the MALBA and directs a library of classics at El Hilo de Ariadna. In addition, two Latin American audiovisual projects based on his work are underway: a film adaptation of Waiting for the Barbarians by the Colombian director Ciro Guerra and a television series based on his "Jesus" trilogy by the Argentine Tristán Bauer.

15. See Fernández (El País), García Ramírez (Letras Libres), EFE (El Espectador), or Carrión (The New York Times: Spanish edition, now cancelled); and compare with Holgate (The Sunday Times), Self (The Times), Goyal (HuffPost: India edition), Preston and Poole (The Guardian), Battersby (Financial Times), Adam White (Independent.ie), and Lowdon $(T L S)$.

16. Coetzee presented "The Old Woman and the Cats" at readings around the world, and it was later published independently in an art catalogue alongside photographs of Berlinde De Bruyckere's exhibition at the Belgian Pavilion of the 2013 Venice Biennale. Three Stories was published by Australia's Text Publishing, and is not available to the UK and US markets. 
17. See McDonald, esp. pp. 303-20.

18. Walkowitz 5, see also 49-91.

19. For Coetzee as a global reference for human rights fiction, see Dawes (World), Anker, and Winter.

20. See Dimitriu's (“Utopia”) re-reading of Coetzee's The Master of Petersburg (1994) and her comparison with The Childhood of Jesus as father-and-son utopias of salvation. For an interpretation of David, Inés, and Simón as a secular "Holy Family" see Dimitriu (“Attachment”).

21. On Coetzee's critical cosmopolitanism, see Loy.

22. E-mail correspondence cited by Hahn's courtesy, February 5, 2020.

\section{Works Cited}

Adam White, Hilary. "From literary big hitters to gripping thrillers-it's the ultimate 2020 books preview." Independent.ie, 4 January 2020, https://www.independent.ie/entertainment/books/from-literary-big-hitters-to-grippingthrillers-its-the-ultimate-2020-books-preview-38830278.html. Accessed 31 January 2020.

Aguilar, Gonzalo. "Clarice Lispector in the Foreign Legion: Vicissitudes of a Reception." Rethinking World Literature Studies in Latin American and Spanish Contexts, special issue of Journal of World Literature 2:1 (2017): 80-91.

Alonso, Carlos. "The Novel without Literature." Novel: A Forum on Fiction 44: 1 (2011): 35.

Anker, Elizabeth. Fictions of Dignity: Embodying Human Rights in World Literature. Ithaca, N.Y.: Cornell University Press, 2012. 
Annesley, James. Fictions of Globalization: Consumption, the Market and the Contemporary Novel. London: Continuum, 2006.

Apter, Emily. Against World Literature: On the Politics of Untranslatability. London and New York: Verso, 2013.

Armstrong, Nancy. "The Affective Turn in Contemporary Fiction." Contemporary Literature 55.3 (2014): 441-65.

---. "The Future in and of the Novel.” Novel: A Forum on Fiction 44.1 (2011): 8-10.

---. "The Migrant Novel: On becoming what we are not." Neoliberalism and Social Reproduction, special issue of Polygraph 27 (2019): 67-83.

Armstrong, Nancy, and Warren Montag. “Are novels Literature?” Novel: A Forum on Fiction 50.3 (2017): 338-50.

Attridge, Derek. "The South According to Coetzee.” Public Books, 14 October 2019, https://www.publicbooks.org/the-south-according-to-coetzee/. Accessed 31 January 2020.

Barnard, Rita. “Coetzee in/as Afrikaans.” Journal of Literary Studies 25.4 (2009): 438-62.

---. "Fictions of the Global.” Novel: A Forum on Fiction 42.2 (2009): 207-15.

Battersby, Doug, “"The Death of Jesus', the latest novel from JM Coetzee.” Financial Times, 2 January 2020, https://www.ft.com/content/ed834ada-1ddd-11ea-81f0-0c253907d3e0. Accessed 31 January 2020.

Beecroft, Alexander. An Ecology of World Literature. London and New York: Verso, 2015. ---. "On the Tropes of Literary Ecology: The Plot of Globalization." Globalizing Literary Genres. Ed. Jernej Habjan and Fabienne Imlinger. London and New York: Routledge, 2016. 195-212. 
Bencomo, Anadeli. “Geopolíticas de la novela hispanoamericana contemporánea: en la encrucijada entre narrativas extraterritoriales e internacionales.” Revista de crítica literaria latinoamericana 69.1 (2009): 33-50.

Berman, Anna A. "The Family Novel (and Its Curious Disappearance)." Comparative Literature 72.1 (2020): 1-18.

Bessière, Jean. Le Roman contemporain ou la problématicité du monde. Paris: Presses universitaires de France, 2010.

Boes, Tobias. "Reading the Book of the World: Epic Representation in the Age of Our Geophysical Agency." Novel: A Forum on Fiction 49. 1 (2016): 96-114.

Brouillette, Sarah. "How Field Theory Can Contribute to Knowledge of the World Literary Space.” Paragraph 35.1 (2012): 10-29.

Calabresi, Stefano. www.letteratura.global. Il romanzo dopo il postmoderno. Einaudi, 2005.

Calabresi, Stefano, ed. Narrare al tempo della globalizzazione. Roma: Carocci Editori, 2016.

Carrión, Jorge. “J. M. Coetzee: un nobel sudafricano, un escritor hispanoamericano.” The New York Times, 4 June 2018, https://www.nytimes.com/es/2018/06/04/espanol/cultura/coetzee-sudafricaespanol.html. Accessed 20 March 2020.

Casanova, Pascale. Le république mondiale des lettres. Paris: Seuil, 1999.

Cheah, Pheng. "World against Globe: Toward a Normative Conception of World Literature." New Literary History 45. 3 (2014): 303-29.

Coetzee, J.M. “In Conversation: J. M. Coetzee with Soledad Costantini.” Azkuna Zentroa, Bilbao, May 29, 2018. https://www.youtube.com/watch?v=4VNk52t-YPM. Accessed 31 January 2020.

---. The Childhood of Jesus. London: Harvill Secker, 2013.

---. The Death of Jesus. London: Harvill Secker, 2019. 
---. The Schooldays of Jesus. London: Harvill Secker, 2016.

Coletti, Vittorio. Romanzo mondo: La letteratura nel villaggio globale. Bologna: Il Mulino, 2011.

Dan, Hansong, and Ewa Wojno-Owczarska. "Introduction: Global Crises and Twenty-FirstCentury World Literature,” special issue of Comparative Literature Studies 55.2 (2018): 245-61.

Damrosch, David. What Is World Literature? Princeton: Princeton University Press, 2003.

Dawes, James. That the World May Know: Bearing Witness to Atrocity. Cambridge: Harvard University Press, 2007.

---. “The Novel of Human Rights.” American Literature 88.1 (2016): 127-57.

De Blasio, Antonella. "Gli autori.” Narrare al tempo della globalizzazione. Ed. Stefano Calabrese. Roma: Carocci editore, 2016. 15-44.

Deckard, Sharae, and Stephen Shapiro. World Literature, Neoliberalism and the Culture of Discontent. Houndmills: Palgrave, 2019.

Deer, Patrick. "British Cosmopolitanism after 1980." The Cambridge Companion to British Fiction Since 1980. Ed. Peter Boxall. Cambridge: Cambridge University Press, 2019. 253-55.

Denning, Michael. “The Novelists' International.” The Novel. History, Geography, and Culture. Ed. Franco Moretti. Vol. 1. Princeton: Princeton University Press, 2006. 70325.

Dimitriu, Ileana. ““Attachment with Detachment': A Post-Secular Reading of JM Coetzee’s Recent Fiction.” British and American Studies 21 (2015): 133-41.

---. 'Utopia and Dystopia: 'A Brave New World' and the case of J.M. Coetzee.” British and American Studies 25 (2019): 133-42. 
Domínguez, César. “Literatura mundial en biblioburro: Un caso procomún de circulación literaria." Re-mapping World Literature: Writing, Book Markets and Epistemologies between Latin America and the Global South. Ed. Gesine Müller, Jorge Locane, Benjamin Loy. Berlin: De Gruyter, 2018. 119-30.

Edwards, Caroline. "The networked novel." The Routledge Companion to Twenty-First Century Literary Fiction. Ed. Robert Eaglestone and Daniel O'Gorman. London and New York: Routledge, 2019. 13-24.

EFE. “Coetzee afirma que sus libros 'no están enraizados al idioma inglés'.” El Espectador, 25 October 2019, https://www.elespectador.com/noticias/cultura/coetzee-afirma-quesus-libros-no-estan-enraizados-al-idioma-ingles-articulo-887791. Accessed 31 January 2020.

English, James F. The Economy of Prestige: Prizes, Awards, and the Circulation of Cultural Value. Cambridge: Harvard University Press, 2008.

Erwin, Lee. "Domesticating the subaltern in the global novel in English." The Journal of Commonwealth Literature 47.3 (2012): 325-39.

Fernández, Laura. “Coetzee continúa su idilio con el español.” El País, 25 May 2019, https://elpais.com/cultura/2019/05/25/actualidad/1558819674_216581.html. Accessed 31 January 2020.

Ganguly, Debjani. This Thing Called the World: The Contemporary Novel as Global Form. Durham: Duke University Press, 2016.

---. “The Global Novel: Comparative Perspectives.” Special issue of New Literary History, 51. 2, (2020).

García Ramírez, Fernando. “La trilogía de Jesús.” Letras Libres, 1 July 2019, https://www.letraslibres.com/mexico/revista/la-trilogia-jesus. Accessed 31 January 2020. 
Gil González, Antonio J. "Hacia una (post)novela (post)nacional.” Nuevos Hispanismos [vol II]. Para una crítica del lenguaje dominante, edited by Julio Ortega. Frankfurt: Iberoamericana-Vervuert, 2012. 231-51.

Goyal, Sana. “50 Books To Look Forward To In 2020.” HuffPost. India Edition, 28 December 2019, https://www.huffingtonpost.in/entry/50-books-to-look-forward-to-in2020_in 5e05c466e4b0843d3604e7b2? guccounter=1. Accessed 31 January 2020.

Gupta, Suman. "Crisis of the Novel and the Novel of Crisis." Canadian Review of Comparative Literature 42.4 (2015): 454-67.

---. Globalization and Literature. Cambridge: Polity Press, 2009.

Habjan, Jernej, and Fabienne Imlinger. Globalizing Literary Genres: Literature, History, Modernity. London and New York: Routledge, 2016.

Haley, Madigan. "Marginal Figures and the Ethos of the Global Novel." Novel: A Forum on Fiction 48.1 (2015): 103-21.

Heise, Ursula K. “Globality, Difference, and the International Turn in Ecocriticism.” PMLA 128. 3 (2013): 636-43.

---. Sense of Place and Sense of Planet: The Environmental Imagination of the Global, Oxford: Oxford University Press, 2008.

Helgesson, Stefan, and Pieter Vermeulen. Institutions of World Literature: Writing, Translation, Markets. London and New York: Routledge, 2016.

Hevia, Elena. “Gabi Martínez: 'Nada es tan peligroso como te cuentan'.” El periódico, 5 May 2007, https://www.elperiodico.com/es/barcelona/20070405/gabi-martinez-nada-es-tanpeligroso-como-te-cuentan-5440622. Accessed 25 February 2020.

Holgate, Andrew. "The Sunday Times books to watch out for in 2020." The Sunday Times, 15 December 2019, https://www.thetimes.co.uk/article/2020-what-to-watch-out-fornext-year-sunday-times-books-gb2dwht8s. Accessed 31 January 2020. 
Horta, Paulo Lemos. "Taste Without Distinction: Foreign Lists in Postwar America.” Interventions 22.3 (2019): 416-32.

Hoyos, Héctor. Beyond Bolaño: The Global Latin American Novel. New York: Columbia University Press, 2015.

Huehls, Mitchum, and Rachel Greenwald Smith. Neoliberalism and Contemporary Literary Culture. Baltimore: Johns Hopkins University Press, 2017.

Irr, Caren. "Toward the World Novel: Genre Shifts in Twenty-First-Century Expatriate Fiction.” American Literary History 23. 3 (2011): 660-79.

Jackson, Jeanne-Marie. “You Are Where You Aren't: Mark Behr and the Not-Quite-Global Novel." Safundi 14.2 (2013): 175-90.

Jay, Paul. Global Matters: The Transnational Turn in Literary Studies. Ithaca: Cornell University Press, 2010.

Jiménez, Chris D. "Nuclear Disaster and Global Aesthetics in Gerald Vizenor's Hiroshima Bugi: Atomu 57 and Ruth Ozeki's A Tale for the Time Being." Comparative Literature Studies 55. 2 (2018): 262-84.

Keith, Joseph. "The novel as Planetary Form.” The Cambridge Companion to the Novel. Ed. Eric Bulson. Cambridge: Cambridge University Press, 2018. 268-83.

Kern, Martin. “Ends and Beginnings of World Literature.” Poetica 49 ( 2017-18): 1-31.

Kirsch, Adam. The Global Novel: Writing the World in the $21^{\text {st }}$ Century. New York: Columbia Global Reports, 2016.

Levin, Stephen M. "Is there a Booker Aesthetic? Iterations of the Global Novel." Critique: Studies in Contemporary Fiction 55.5 (2014): 477-93.

Locane, Jorge J. De la literatura latinoamericana a la literatura (latinoamericana) mundial. Berlin: De Gruyter, 2019. 
Loy, Benjamin. "The precarious state of the art: Writing the Global South and critical cosmopolitanism in the works of J.M. Coetzee and Roberto Bolaño.” Re-mapping World Literature. Ed. Gesine Müller, Jorge Locane, Benjamin Loy. Berlin: De Gruyter, 2018. 91-116.

Lowdon, Claire. "It's a dog's life: Following the leads in the late novels of J. M. Coetzee." TLS, 10 January 2020, 4-5. https://www.the-tls.co.uk/articles/its-a-dogs-life/. Accessed March 7, 2020.

Marín Yarza, Maribel. “Entrevista a J. M. Coetzee” El País, 29 January 2018, https://elpais.com/cultura/2018/01/28/actualidad/1517098470_378551.html. Accessed 31 January 2020.

Marling, William. Gatekeepers: The Emergence of World Literature and the 1960s. Oxford: Oxford University Press, 2016.

Martínez, Gabi. Sudd. Madrid: Alfaguara, 2007.

Marx, John, and Nancy Armstrong. The Novel and Neoliberalism, special issue of Novel: A Forum on Fiction 51.2 (2018).

McDonald, Peter D. The Literature Police: Apartheid Censorship and Its Cultural Consequences. Oxford: Oxford University Press, 2009.

Morace, Rosanna. "Il romanzo tra letteratura-mondo e global novel." Tricontre. Teoria Testo Traduzione 2 (2014): 103-22.

Moraru, Christian. Reading for the Planet: Toward a Geomethodology. Ann Arbor: University of Michigan Press, 2015.

---. “'World,' 'globe,' 'planet': comparative literature, planetary studies, and cultural debt after the global turn.” American Comparative Literature Association, The 2014-2015 report on the state of the discipline of comparative literature, Website - Paradigms: http://stateofthediscipline.acla.org. Accessed 6 February, 2020. 
Moretti, Franco. “Conjectures on World Literature.” New Left Review 1 (2000): 54-68.

---. “More Conjectures on World Literature.” New Left Review 20 (2003): 73-81.

Nadiminti, Kalyan. "The Global Program Era: Contemporary International Fiction in the American Creative Economy.” Novel: A Forum on Fiction 51.3 (2018): 376-98.

O’Brien, Susie, and Imre Szeman. "Introduction: The Globalization of Fiction/the Fiction of Globalization.” The South Atlantic Quarterly 100.3 (2001): 603-26.

Poole, Steven. "The Death of Jesus by JM Coetzee review." The Guardian, 4 January 2020. https://www.theguardian.com. Accessed 31 January 2020.

Preston, Alex. "The Death of Jesus by JM Coetzee review." The Guardian, 31 December 2019 https://www.theguardian.com. Accessed 31 January 2020.

Robbins, Bruce. The Beneficiary. Durham: Duke University Press, 2017.

Rosen, Jeremy. "Everywhere at Once and Nowhere Specific: The Generic Sites of the Contemporary Global Novel.” ASAP/Journal 2.3 (2017): 627-52.

Rotger, Neus, Diana Roig-Sanz, and Marta Puxan-Oliva. "Introduction: Towards a CrossDisciplinary History of the Global in the Humanities and the Social Sciences." Journal of Global History 14.3 (2019): 325-34.

Sánchez Prado, Ignacio M. Strategic Occidentalism: On Mexican Fiction, the Neoliberal Book Market, and the Question of World Literature. Evanston: Northwestern University Press, 2018.

Self, John. "The Death of Jesus by JM Coetzee review." The Times, 19 December 2019, https://www.thetimes.co.uk/article/the-death-of-jesus-by-j-m-coetzee-reviewxnn5hkh27. Accessed 31 January 2020.

Shaw, Kristian. Cosmopolitanism in twenty-first century fiction. Houndmills: Palgrave Macmillan, 2017. 
---. "Globalization." The Routledge Companion to Twenty-First Century Literary Fiction. Ed. Robert Eaglestone and Daniel O'Gorman. Routledge, 2019. 25-35.

Siskind, Mariano. Cosmopolitan Desires: Global Modernity and World Literature in Latin America. Evanston: Northwestern University Press, 2014.

Slaughter, Joseph R. Human Rights, Inc.: The World Novel, Narrative Form, and International Law. New York: Fordham University, 2007.

Spivak, Gayatri. Death of a Discipline. New York: Columbia University Press, 2003.

Tanaka, Shouhei. "The Great Arrangement: Planetary Petrofiction and Novel Futures.” MFS Modern Fiction Studies 66.1 (2020): 190-215.

Taylor, Matthew A. “At Land's End: Novel Spaces and the Limits of Planetarity.” Novel: A Forum on Fiction 49.1 (2016): 115-38.

Van Der Vlies, Andrew. "Publics and Personas." The Cambridge Companion to J.M. Coetzee. Ed. Jarad Zimbler. Cambridge University Press, 2020. 234-47.

Viljoen, Louise. "Afrikaans Literature in / and the World Republic of Letters: The Case of Koos Prinsloo and S.J. Naudé”, Journal of Literary Studies 35.1 (2019): 59-79.

Walkowitz, Rebecca L. Born Translated: The Contemporary Novel in an Age of World Literature. New York: Columbia University Press, 2015.

Warwick Research Collective. Combined and Uneven Development: Towards a New Theory of World-Literature. Liverpool: Liverpool University Press, 2015.

Winter, Sarah. "The Magistrate, the Camp, and the Novel: J.M. Coetzee and the Subject of Human Rights.” Novel: A Forum on Fiction 47.2 (2014): 261-83. 